\title{
第14回 多摩大腸疾患㤅話会
}

\author{
日時：平成 13 年 11 月 10 日（土） \\ 当番世話人：江上 格（日本医科大学付属多摩永山病院） \\ I 部: 主演題 \\ $1 \sim 3$ 座長 正木 忠彦 (杏林大学 第 1 外科) \\ $4 \sim 8$ 座長 勝又 健次（東京医科大学八王子医療センター） \\ II 部：特別講演「外科における癌研究と展望」 \\ 森 正樹（九州大学生体防御医学研究所 外科） \\ (座長) 江上格（日本医科大学付属多摩永山病院）
}

\section{1. 当院における大腸癌肝転移症例の検討}

東京医科大学八王子医療センター 消化器外科 ${ }^{1)}$ 、外科第 3 講座 ${ }^{2}$ 、

鈴木 芳明 ${ }^{1}$ 、“勝又 健次 ${ }^{1)}$ 、壽美 哲生 ${ }^{1)}$ 、 山下 晋矢 ${ }^{1)}$ 、高木 黃人 ${ }^{1)}$ 、加藤 文昭 ${ }^{1)}$ 、 向出 将( ${ }^{1)}$ 、鈴木 彰二1)、太田 喜洋 ${ }^{1)}$ 、 富岡 英則 ${ }^{1)}$ 、青木 達哉 ${ }^{2)}$ 、小柳 泰久 ${ }^{2)}$ 、 【目的】大腸癌肝転移例に対方る肝切除術及 び肝動注化学療法（動注）の治療効果を検討 した。

【方法】（1）1990年4月〜2001年8月までに肝 転移を根治的に切除しえた27例を対象とし、 予後及び予後規定因子を検討した。さらに再 発形式につき検討した。（2）同期間に切除不 能な肝転移巣に対し動注を行った22例を対象 として治療効果を検討した。

【結果】（1）肝切除後 1,3,5年生存率は 92,79,56\%であった。原発巣リンパ節（一）群. 転移巣が単発の群・最大径 $3 \mathrm{~cm}$ 未満の群で予後 良好な傾向が見られた。再発形式は残肝再発 が最多で、再切除を行った4例中3例は無再発 生存中である。（2）動注群の1,2,3年生存率は $80,26,18 \%$ 、非施行群の 1,2 年生存率は共に $20 \%$ で、3年生存例はなく、動注群で有意に予後良 好であった。

【結語】大腸癌肝転移の根治的切除例では予 後良好であった。残肝再発例に対しても積極 的に再切除すべきであると考えられた。動注 は有効な治療法であると考えられた。

\section{3.ラジオ波凝固療法による大腸癌肝転移の} 治療経䮎

青梅市立総合病院外科

杉崎 勝好、正木 幸善、西田 正人、

菖蒲 洋大、縄田 寛、藤田 豊樹、

森田 明夫、山田 忠義

当科では平成 11 年12月より、肝腫瘍に対しラ ジオ波凝固療法による治療を導入した。大腸 癌肝転移の治療例は10例あるが、まだ治療効 果の長期的検討ができる段階にはなく治療経 験として報告した。使用機種はRF2000、穿刺 電極はLeveen needle 3,5cmのものを用いた。 症例は原発部位は結腸 8 例直腸 2 例、同時性 4例、異時性6例、転移栄は単発5例、多発5例。 RFのアプローチは局麻5例、右開胸 1 例、開腹 は4例であった。結果として異時性単発例の3 例が根治療法となった。他臓器転移の併存す る症例において、肝転移を予後決定因子とし ないために治療した 3 例では目的は達成できた ものと考えている。さらに、多発症例にも適 用し、肝動注などと併用することで、延命効 果を狙ったが、評価は難しい。ラジオ波凝固 療法は十分な凝固範囲が得られれば侵襲少な く確実に根治させることができるため、今後 の検討が期待される。 
4. 原発巣切除後に同時性肝・肺転移に対す る5FU/高濃度 1-LV療法が著効したS状結 腸癌の1例

防衛医科大学校 第 1 外科

○相澤 亮、藤本 肇、橋口陽二郎、

上野 秀樹、石川 啓一、前島 純典、

小泉 和也、望月 英隆

$\mathrm{S}$ 状結腸癌同時性肝・肺転移に対し、原発巣の 切除後に $5 \mathrm{FU}$ /高用量1-LV療法が著効した例を 経験したので報告する。

【症例】52歳、男性。便秘を主訴に、全周性2 型のS状結腸癌の診断。腹部 CT検查にて肝

$\mathrm{S}_{3}, \mathrm{~S}_{5}, \mathrm{~S}_{6}$ に各 $22,15,20 \mathrm{~mm}$ 、胸部CT検查にて肺右 $\mathrm{S}_{1}, \mathrm{~S}_{7}, \mathrm{~S}_{9}$, 左 $\mathrm{S}_{10}$ に各 $2,8,20,20 \mathrm{~mm}$ 大の同時性肝 - 肺 転移を認めた。

【手術】平成13年2月に高位前方切除術施行 (well,P0,H2,se,n $n_{4}(+), \mathrm{M}(+)$, stageIV)。

【術後経過】25PODより $5 \mathrm{FU} 1000 \mathrm{mg} / \mathrm{l}-\mathrm{LV}$ $425 \mathrm{mg}$ を週1回静注、4投 2 休を1クールとして 開始。肝転移巣は2クール終了後のCT以降描 出されず、肺転移巣は2クール終了後のCTで 右 $\mathrm{S}_{9}(20 \mathrm{~mm})$ が $10 \mathrm{~mm}$ 一縮小、その他の転移巣 は全て消失し、さらに4クール終了後は、右 $\mathrm{S}_{9}$ に径 $5 \mathrm{~mm}$ のcoin lesionを認めるのみとなり、 PRと判断された。化学療法の副作用はgradel の嘔気・下㾁を認めたが、対症療法により軽快 した。5クール目以降、grade2の白血球減少を きたし、5FUを $25 \%$ 減量し現在6クール目を継 続中である。

【まとめ】大腸癌同時性肝 - 肺転移に対し切 除手術および全身化学療法を施行。著明な腫 瘍縮小効果と、9ヶ月に及ぷ局所コントロール を得ている症例を経験した。

\section{5. 腸閉塞症例における画像診断} MR Intestinographyの検討 杏林大学 第一外科 ${ }^{(1)}$ 、同放射線科 ${ }^{(2)}$

松岡 弘芳(1)、正木 忠彦(1)、杉山 政則 ${ }^{(1)}$ 、

跡見 裕 ${ }^{(1)}$ 、高原太郎 ${ }^{(2)}$ 、蜂屋 順一 ${ }^{(2)}$

(目的) 腸閉塞症例に対し術前にMR Intestinography（MR-I）を施行し、その有用性を検討 することを目的とした。

（対象·方法）対象27例をretrospectiveに検討 した。MR-Iは主に冠状断脂肪抑制T1強調像と $\mathrm{T} 2$ 強調像を撮影し、結果を手術所見と比較し た。

（結果）MR-Iで診断した27例中25例で閉塞部 位は一致した (92.5\%)。原因診断（腫瘍性·非 董瘍性の別）でも27例中 25 例で一致した (92.5\%)。閉塞部位診断にはtransition zone、 残渣サイン、MIP画像を用いた立体表示、更 にCine撮像によりdynamicに腸管の動き・静 止部位の同定も可能であった。

（結語）MR-Iは閉塞部位・原因診断に有用で、 多彩な撮像技術の導入で診断がより明確にさ れるものと思われた。

\section{6. 横行結腸癌術後脾茞転移の 1 切除例}

公立昭和病院外科

竹下 勇太郎、小林 薰、照屋 正則、

清水 清一郎、藤田 敦、西尾 洋介、

伊藤 精彦、森田 恒治、浅合 觯治、

荒木 駿二

一般に悪性腫瘍の脾臓転移は末期癌の全身転 移の一部として見られることはあるが、臨床 的に切除の対象になることは稀である。今回 われわれは横行結腸癌術後 4 年 8 ケ月後に肝転 移を切除し、さらに2年後、初回手術からは6 年8ヶ月後に孤立性脾臓転移を認め、脾臓摘出 術を行った極めて稀な1例を経験したので文献 的考察を加え報告する。症例は64才男性。 1994年12月16日横行結腸癌に対して横行結腸 切除術施行。99年7月多発肝転移に対して肝切 除術施行。2001年9月転移性脾腫晹の診断で脾 臓および䐙尾部切除術を施行した。病理結果 は高分化腺癌で結腸癌の脾岿転移と診断した。 大腸癌の脾缄転移が切除の適応となることは 稀であり、本邦報告例は35例であった。孤立 性脾蔵転移切除例で長期生存の報告例もある ため皘極的に手術を施行するべきと考えるが 術後化学療法に上る他臓器転移の予防が必要 と思われた。 


\section{7.腸重積を伴った大腸癌の 1 例}

(財) 結核予防会 新山手病院 外科 田代 浄、西蓮寺 隆之、千坂 正毅、 守 純一、長田 功

東京大学医科学研究所

江里口 正純

東京医科大学八王子医療センター 外科学

第5講座

長尾 桓

成人の腸重積症は比較的稀で、ほとんどが器 質的疾患を有し、癌によるものが大部分を占 めると報告されている。症例は39歳男性。主 訴は腹痛、䟚昍。筫血を認め腹部全体は膨隆、 圧痛を認め、CEA、CA19-9は正常値、便潜血 は陰性。X線で腹部全体を占める小腸ガスを 認め、右季助部に腫瘤を触知。エコーでは、 右季肋部に $7 \times 7 \mathrm{CM}$ の同心円状に層が配列する ターゲットライクサインを認め、腹部CTでも 上行結腸にターダットライクサインを認め、 注腸検查では上行結腸にカニ爪様陰影、内視 鏡では、上行結腸に隆起性病変を認めadeno carcinomaの診断、手術を施行。腸重積は結腸 結腸型で整復は行わず、右半結腸切除、3群り ンパ節郭清術を施行。術後経過は良好で 47 病 日に退院となる。診断的価值の高いCT、US 検查は第一選択であり、本症例では術前に十 分な手術方針をたてることが可能であった一 例を経験したのでここに報告する。

\section{8. 大腸癌肝転移肝切除後の肺再発例に関する}

\section{検討}

都立府中病院 外科

高西 喜重郎、松本 潤、高橋 直樹、 南 智仁、由里 樹旺、高見 実、

大島 哲、井上 仁

大腸癌肝転移肝切除57例中、肺転移は13例 （22.8\%）に見られた。肺転移の見られなかっ た症例の 5 年生存率は $44 \%$ であたが、肺転移 を来した症例の5年生存例はなく、治療上の問 題点であった。肺転移を来した症例の臨床経 過を見ると、他缄器再発を合併した症例は9例 (69\%) であり、肝・肺は4例 $(30.8 \%) 、$ 肺の みの再発例は見られず、全身病としての予防 的治療の必要性が示唆された。肺再発危険群 を設定するために肝転移栄組織での thymidine phosphorylaseの测定は有用であることを確認 中であるとともに、肺再発予防のためにCPT11、1-LV、5-FUによる治療が有用か否か検討 中である。

\section{9. 大腸癌肺転移切除症例の検討}

日本医科大学付属多摩永山病院 外科

山本 英希、江上 格、松島 申治、

渡邊 秀裕、長谷川博一、宮本昌之、

飯田 信也、中村 孝、横山 正、

鈴木 成治、寺本 忠、下村 隆保、

大川 敬一、高島 良樹、萩原 信敏、

河原 理子、吉周 正智

【目的】大腸癌肺転移に対する肺切除例につ

いて検討した。

【対象】過去20年間に経験した30例。

【成績】(1)全症例の3年生存率 $46.2 \% 、 5$ 年生存 率20.0\%。(2)肺切除前CEA值は同時性肺転移例 で2.6-1186.0ng/d1、大腸癌術後肺転移例で $1.5-53.5 \mathrm{ng} / \mathrm{d} 1$ 。CEA值による生存率に有意 差はないが、CEA $\geqq 35 \mathrm{ng} / \mathrm{d} 1$ ではいずれも6 18か月以内に死亡。一方、 $\mathrm{CEA}<5.0 \mathrm{ng} / \mathrm{d} 1$ の 11 例中、術後 2 年以内の死亡は 3 例。(6)縦隔り ンパ節転移の有無で生存率に有意差はないが、 リンパ節転移例は30か月以内に死亡。(9)肝転 移例7例の3年生存率は $40 \%$ で非肝転移例と の有意差はなし。全例、化学療法を行ったが、 肺ないし旰に再転移し、肝再転移に対しては MCT and/or RFAを行った。肺再転移がなく 肝再転移の症例で3年以上の生存例あり。

【結論】肺転移に対して安易な手術適応は慎 まなければならないが、個数がおおむね2個ま でであれば、術前CEA值や維隔リンパ節転移 の有無を参考に、朋転移症例も含めて積極的 に適店を搪大してもよいと思われる。 